\title{
In vitro screening for antiviral activity of Turkish plants revealing methanolic extract of Rindera lanata var. lanata active against human rotavirus
}

Andrea Civra ${ }^{1}$, Rachele Francese ${ }^{1}$, Davide Sinato ${ }^{1}$, Manuela Donalisio ${ }^{1}$, Valeria Cagno ${ }^{1}$, Patrizia Rubiolo², Ramazan Ceylan ${ }^{3}$, Ahmet Uysal', Gokhan Zengin ${ }^{3}$ and David Lembo ${ }^{1 *}$

\begin{abstract}
Background: Human rotavirus (HRoV) is the leading cause of severe gastroenteritis in infants and children under the age of five years. No specific antiviral drug is available for HRoV infections and the treatment of viral diarrhea is mainly based on rehydration and zinc treatment. In this study, we explored medicinal plants endemic to Turkey flora as a source of anti-HRoV compunds.

Methods: We performed an antiviral screening on Ballota macrodonta, Salvia cryptantha and Rindera lanata extracts by focus reduction assay. The extract with the highest selectivity index (SI) was selected; its antiviral activity was further confirmed against other HRoV strains and by virus yield reduction assay. The step of viral replicative cycle putatively inhibited was investigated by in vitro assays.

Results: The methanolic extract of $R$. lanata (Boraginaceae) showed the most favourable selectivity index. This extract exhibited a dose-dependent inhibitory activity against three different HRoV strains ( $E C_{50}$ values ranging from $5.8 \mu \mathrm{g} / \mathrm{ml}$ to $25.5 \mu \mathrm{g} / \mathrm{ml}$ ), but was inactive or barely active against other RNA viruses, namely human rhinovirus and respiratory syncytial virus. The $R$. lanata extract targets the early steps of HRoV infection, likely by hampering virus penetration into the cells.

Conclusion: These results make the $R$. lanata methanolic extract a promising starting material for a bioguidedfractionation aimed at identifying anti-HRoV compounds. Further work is required to isolate the active principle and assess its clinical potential.
\end{abstract}

\section{Background}

Gastroenteritis accounts for almost $20 \%$ of the deaths of children under five years (National Collaborating Centre for Women's and Children's Health. 2012). Viruses cause approximately $70 \%$ of acute gastroenteritis, with rotavirus infection frequently implicated in cases that require hospitalization [1, 2]. Human rotavirus (HRoV, family Reoviridae, genus Rotavirus) is responsible for 114 million episodes of diarrhea, 25 million clinic visits, 2.4 million hospital admissions, and more than 500,000 deaths in

\footnotetext{
* Correspondence: david.lembo@unito.it

${ }^{1}$ Department of Clinical and Biological Sciences, University of Torino, S. Luigi Gonzaga Hospital, Regione Gonzole, 10, 10043 Orbassano, Torino, Italy Full list of author information is available at the end of the article
}

children up to age 5 occur worldwide annually [3]. While most of the episodes are mild, about $10 \%$ of cases lead to dehydration requiring a doctor visit, and in resourceconstrained nations, one in 250 children will die from this dehydration [4-7]. In Europe, HRoV infection accounts for more than $50 \%$ of hospitalizations for gastroenteritis and about one-third of emergency department visits $[1,4$, 8]. At present, the treatment of viral diarrhea is based on fluid replacement and zinc treatment in order to prevent dehydration and to decrease the severity and duration. So far, no specific antiviral drug is available to treat $\mathrm{HRoV}$ infections. Discovering novel, safe and effective antiviral molecules is a difficult task. One strategy is to explore plants as a source of novel active compounds due to the 
large structural diversity of natural products. Indeed, several studies reported on anti-HRoV activity by plant extracts [9-14]. In this context, we performed an antiviral screening of three plants endemic to Turkey flora and here we report on the anti-HRoV activity of Rindera lanata (Boraginaceae). Boraginaceae is a plant family represented by about 2,000 species in the world [15]. The genus Rindera includes about 25 species distributed mainly in Central and Western Asia [16], four of which growing in Turkey, namely $R$. lanata, $R$. caespiota, $R$. albida and $R$. dumani. Rindera species are widely known as "Yünlü gelin" and used as an antiinflammatory agent in Anatolian folk medicine [17]. $R$. lanata is used to alleviate joint pains in Iranian folk medicine [18]. However, to the best of our knowledge, $R$. lanata was neither traditionally used nor scientifically investigated for antiviral properties. The present study reports the anti-HRoV potency, the spectrum of antiviral activity, and the probable mechanisms of antiviral action of the $R$. lanata methanol extract.

\section{Methods \\ Chemicals}

Quinic acid (>98\%), malic acid (>99\%), cholorogenic acid (>95\%), protocatechuic acid (>97\%), caffeic acid (>98\%), $p$-coumaric acid (>98\%), rosmarinic acid (>96\%), rutin ( $>94 \%$ ), hesperidin (>97\%) and hyperoside (>97\%) were purchased from Sigma-Aldrich (Germany). Apigenin (>99\%) and rhamnetin (>99\%) were purchased from Fluka (Germany).

\section{Plant material and extraction}

Taxonomic identification of the plant materials were confirmed by the senior taxonomist Dr. Murad Aydin Sanda, from the Department of Biology, Selcuk University. The voucher specimens were deposited at the Konya Herbarium of Department of Biology, Selcuk University, Konya-Turkey. Rindera lanata (Lam.) Bunge var. lanata (Lam.) Bunge (family: Boraginaceae) was collected from Balcilar-Taskent, Konya-Turkey, May 2014, (Voucher No: GZ 1410). Salvia cryptantha Montbret et Aucher ex Bentham (family: Lamiaceae) was provided by Selcuk University, Aladdin Keykubat Campus, Yukselen village- Campus road, Konya-Turkey, June 2014, (Voucher No: GZ 1421). Ballota macrodonta Boiss. et Bal (family: Lamiaceae): was collected from Camardi, Mazmili Mountain, Nigde-Turkey, June 2014 (Voucher No: 1425).

The plant materials were dried at room temperature. The air-dried aerial parts (leaves, stem, flowers) were collected as a mix (10 g) and were macerated with $250 \mathrm{~mL}$ of methanol at room temperature for $24 \mathrm{~h}$. Methanol was then removed with a rotary evaporator at $40{ }^{\circ} \mathrm{C}$. The extracts were stored at $+4{ }^{\circ} \mathrm{C}$ until analyzed.
Yield of these extracts were $17.83 \%, 14.86 \%$ and $4.90 \%$, respectively.

For both cell viability assays and infectivity assays, the extracts were reconstituted in sterile methanol, to a concentration of $25 \mathrm{mg} / \mathrm{ml}$. Every experiment was performed with freshly resuspended extracts.

\section{LC-MS/MS analysis}

LC-MS/MS analyses of the phenolic compounds were performed on a Shimadzu Nexera UHPLC system coupled to a triple quadrupole LC-MS8040 system equipped with an ESI source operating in both positive and negative ionization modes. The liquid chromatograph was equipped with LC-30 AD binary pumps, DGU-20A3R degasser, CTO-10ASvp column oven and SIL-30 AC autosampler. The chromatographic separation was performed on a $\mathrm{C} 18$ reversed-phase Inertsil ODS-4 (150 mm $\times 4.6 \mathrm{~mm}, 3 \mu \mathrm{m}$ particle size, GL Sciences, The Netherlands) analytical column. The column was maintained at $40{ }^{\circ} \mathrm{C}$. The elution gradient consisted of mobile phase with eluent A (water, $5 \mathrm{mM}$ ammonium formate and $0.1 \%$ formic acid) and eluent $B$ (methanol, $5 \mathrm{mM}$ ammonium formate and $0.1 \%$ formic acid). The mobile phase gradient was as follows; from $40 \%$ to $90 \%$ eluent B in $20 \mathrm{~min}$, then $90 \%$ B for $4 \mathrm{~min}$. The flow rate of the mobile phase was $0.5 \mathrm{~mL} / \mathrm{min}$ and the injection volume $4 \mu \mathrm{L}$.

MS conditions were: interface temperature; $350{ }^{\circ} \mathrm{C}$, DL temperature; $250{ }^{\circ} \mathrm{C}$, heat block temperature; $400{ }^{\circ} \mathrm{C}$, nebulizing gas flow (Nitrogen); $3 \mathrm{~L} / \mathrm{min}$ and drying gas flow (Nitrogen); $15 \mathrm{~L} / \mathrm{min}$. LC-MS/MS data were collected and processed by LabSolutions software (Shimadzu, Kyoto, Japan). The multiple reaction monitoring (MRM) mode was used to quantify the analytes by adopting two or three transitions per compound, the first one for quantitative purposes and the second and/or the third one for confirmation. These analytical conditions have been successfully used to analyze other plant matrices [19-21].

\section{Cell lines and viruses}

African green monkey kidney epithelial cells (MA104) and human epithelial adenocarcinoma HeLa cells (ATCC ${ }^{\oplus}$ CCL-2) were propagated in Dulbecco's Modified Eagle Medium (DMEM; Sigma, St. Louis, MO) supplemented with $1 \%(\mathrm{v} / \mathrm{v})$ Zell Shield (Minerva Biolabs, Berlin, Germany) and heat inactivated, 10\% (v/v) fetal bovine serum (Sigma). Human epithelial cells HEp-2 (ATCC ${ }^{\oplus}$ CCL-23) were grown as monolayers in Eagle's minimal essential medium (MEM) (Gibco/BRL, Gaithersburg, MD) supplemented with 10\% FBS and $1 \%$ antibiotic-antimycotic solution. HRoV strains Wa (ATCC ${ }^{\oplus}$ VR-2018), HRoV 408 (ATCC ${ }^{\oplus}$ VR-2273) and DS-1 (ATCC ${ }^{\ominus}$ VR-2550) were purchased from ATCC; virus was activated with $5 \mu \mathrm{g} / \mathrm{ml}$ of porcine pancreatic 
trypsin type IX (Sigma, St. Louis, Mo.) for $30 \mathrm{~min}$ at $37^{\circ} \mathrm{C}$ and propagated in MA104 cells by using DMEM containing $0.5 \mu \mathrm{g}$ of trypsin per $\mathrm{ml}$ as described previously [22]. Respiratory Syncytial Virus (RSV) strain A2 (ATCC ${ }^{\circ}$ VR1540) was propagated in HEp-2 and titrated by the indirect immunoperoxidase staining procedure using an RSV monoclonal antibody (Ab35958; Abcam, Cambridge, United Kingdom) as described previously [23]. Human rhinovirus (HRhV) 1A (ATCC ${ }^{\circ}$ VR-1559) was cultured in HeLa cells, at $34{ }^{\circ} \mathrm{C}$, in a humidified $5 \% \mathrm{CO}_{2}$ incubator. When the full cytopathic effect (CPE) developed, cells and supernatants were harvested, pooled, frozen and thawed three times, clarified and stored at $-70{ }^{\circ} \mathrm{C}$. HRhV titers were determined by the standard plaque method as described previously [22].

\section{Cell viability assay}

Cells were seeded at a density of $5 \times 10^{3} /$ well in 96 -well plates and treated the following day with seriallydiluted methanol extracts of $B$. macrodonta, S. cryptantha or $R$. lanata $(1.2 \mu \mathrm{g} / \mathrm{ml}$ to $1666 \mu \mathrm{g} / \mathrm{ml})$ to generate doseresponse curves. Control wells (100\% of viability) were prepared by treating cells with equal volumes of methanol, corresponding to $6.7 \%(\mathrm{v} / \mathrm{v})$ to $0.0048 \%(\mathrm{v} / \mathrm{v})$ in cell media. After $24 \mathrm{~h}$ of incubation, cell viability was determined using the CellTiter 96 Proliferation Assay Kit (Promega, Madison, WI, USA), and following the manufacturer's instructions. Absorbances of both treated $\left(\mathrm{Abs}_{\mathrm{T}}\right)$ and untreated $\left(\mathrm{Abs}_{\mathrm{METH}}\right)$ samples were measured using a Microplate Reader (Model 680, BIORAD) at $490 \mathrm{~nm}$. The $\%$ of cell viability was calculated according to the following formula: $\left(\mathrm{Abs}_{\mathrm{T}} \mathrm{X} 100\right) / \mathrm{Abs}_{\mathrm{METH}}$. The $50 \%$ cytotoxic concentration $\left(\mathrm{CC}_{50}\right)$ was determined using logarithmic viability curves. Where possible, a selectivity index (SI) was calculated by dividing the $\mathrm{CC}_{50}$ by the $\mathrm{EC}_{50}$ value.

\section{Rotavirus inhibition assays}

The anti-HRoV efficacy of methanol extracts of B. macrodonta, S. cryptantha and $R$. lanata was determined by focus reduction assay. Assays of inhibition of rotavirus infectivity were carried out with confluent MA104 cell monolayers plated in 96-well trays, as described elsewhere [22]. Cells were treated for $2 \mathrm{~h}$ at $37{ }^{\circ} \mathrm{C}$ with methanol extract of $R$. lanata, at concentrations ranging from 1.2 to $300 \mu \mathrm{g} / \mathrm{ml}$ in serum-free medium prior to virus addition. $\mathrm{HRoV}$ infection was performed at a multiplicity of infection (MOI) of 0.02 for $1 \mathrm{~h}$ at $37^{\circ} \mathrm{C}$, in presence of the methanol extract unless otherwise stated. Infected cells were washed with serum-free medium, fresh methanol extract was added, and cells were incubated in this medium at $37^{\circ} \mathrm{C}$ in a humidified incubator in $5 \%$ (vol/vol) $\mathrm{CO}_{2}-95 \%$ (vol/vol) air. For time of addition assays, serial dilutions of extracts were added on cells alternatively $2 \mathrm{~h}$ before infection or during infection or post infection.
Control samples were prepared by treating cells with culture medium supplemented with equal volumes of methanol and taken as $100 \%$ of infection. After $16 \mathrm{~h}$ of incubation, infected cells were fixed with cold acetonemethanol (50:50), and viral titers determined by indirect immunostaining by using a mouse monoclonal antibody directed to human rotavirus VP6 (0036; Villeurbanne, France), and the secondary antibody peroxidase-conjugated AffiniPure $\mathrm{F}\left(\mathrm{ab}^{\prime}\right)_{2}$ Fragment Goat Anti-Mouse IgG $(\mathrm{H}+\mathrm{L})$ (Jackson ImmunoResearch Laboratories Inc., 872 W. Baltimore Pike, West Grove, PA 19390). Blockade of viral infectivity is expressed as mean $\% \pm \mathrm{SD}$. Where possible, anti-viral effective concentration $\left(\mathrm{EC}_{50}\right)$ values were calculated by regression analysis using the dose-response curves generated from the experimental data, using PRISM 4 (GraphPad Software, San Diego, CA, U.S.A.).

\section{RSV inhibition assay}

HEp-2 cells were first seeded (at $8 \times 10^{3}$ cells/well) in 96 well plate. The methanol extract of $R$. lanata was serially diluted in medium (from 300 to $0.4 \mu \mathrm{g} / \mathrm{ml}$ ) and incubated with cells for $2 \mathrm{~h}$ at $37{ }^{\circ} \mathrm{C}$, then mixtures of extracts and virus (MOI 0.01) were added to cells to allow the viral adsorption for $3 \mathrm{~h}$ at $37^{\circ} \mathrm{C}$; the monolayers were then washed and overlaid with $1.2 \%$ methylcellulose medium containing serial dilutions of extract. Control wells $(100 \%$ of infection) were prepared by treating cells with equal volumes of methanol. Three days post-infection, cells were fixed with cold methanol and acetone (50:50) for $1 \mathrm{~min}$ and subjected to RSV-specific immunostaining. Immunostained plaques were counted, and the percent inhibition of virus infectivity was determined by comparing the number of plaques in treated wells with the number in untreated control wells.

\section{Rhinovirus inhibition assay}

HeLa cells were first seeded (at $8 \times 10^{4}$ cells/well) in 24 well plates. $24 \mathrm{~h}$ later the methanol extract of $R$. lanata was serially diluted in medium (from $300 \mu \mathrm{g} / \mathrm{ml}$ to $0.4 \mu \mathrm{g}$ / $\mathrm{ml}$ ) and added to cell monolayers. After $2 \mathrm{~h}$ of incubation $\left(37{ }^{\circ} \mathrm{C}, 5 \% \mathrm{CO}_{2}\right)$, medium was removed and infection was performed with $200 \mu \mathrm{L} /$ well with HRhV 1A (MOI 0.0002) and different concentrations of the extract. The infected cells were incubated at $34{ }^{\circ} \mathrm{C}$ for $1 \mathrm{~h}$, then washed with medium, and overlaid with a $1: 1$ combination of $1.6 \%$ SeaPlaque Agarose and 2X DMEM containing the extract. Control wells (100\% of infection) were prepared by treating cells with equal volumes of methanol. The plates were incubated at $34{ }^{\circ} \mathrm{C}$ for 3 days. After incubation, the plates were fixed with $7.5 \%$ formaldehyde (Fluka) and stained with crystal violet (Sigma, St. Louis, Mo.). The number of plaques formed was counted. 


\section{Assay of rotavirus yield}

To test the ability of $R$. lanata extract to inhibit multiple cycles of HRoV replication, confluent MA104 cells in 24-well trays were infected with trypsin-activated Wa rotavirus (MOI 0.02) for $1 \mathrm{~h}$ at $37{ }^{\circ} \mathrm{C}$ and washed as above. Cells were incubated in medium supplemented with $0.5 \mu \mathrm{g} / \mathrm{ml}$ porcine trypsin and 1.2, 3.6, 11, 33, 100, $300 \mu \mathrm{g} / \mathrm{ml}$ of $R$. lanata extract. Infected cells and cell supernatants were harvested at $48 \mathrm{~h}$ post infection and virus titers determined by indirect immunostaining of MA104 cell monolayers inoculated with serial dilutions of the samples. The assay was performed in triplicate. One-way analysis of variance (ANOVA), followed by the Bonferroni test, was used to assess the statistical significance of differences in virus titers. Significance was set at $95 \%$ level.

\section{Virus inactivation assay}

Trypsin-activated HRoV Wa was incubated for $2 \mathrm{~h}$ at $4{ }^{\circ} \mathrm{C}$ in presence of $100 \mu \mathrm{g} / \mathrm{ml}$ of $R$. lanata extract. After this incubation, both treated and untreated viruses were titrated. Viral yields were determined by indirect immunostaning, by counting the number of infective events at dilutions at which the extract was no more active (i.e. 1:1024, 1:2048, 1:4096).

\section{Entry assays}

In order to test the effect of $R$. lanata methanol extract on the rotavirus-cell penetration process, an entry assay was performed. Briefly, MA104 cells were cultured to confluence in 96-well trays; cells were washed twice with DMEM and then cooled on ice for $20 \mathrm{~min}$. Activated virus, which had been cooled to $4{ }^{\circ} \mathrm{C}$, was allowed
Table 1 Antiviral activity of R. lanata, B. macrodonta and S. cryptantha methanolic extract against HRoV Wa

\begin{tabular}{lllll}
\hline HRoV strain & Source & EC50 $(\mu \mathrm{g} / \mathrm{ml})-$ & $\mathrm{CC}^{\mathrm{a}}(\mu \mathrm{g} / \mathrm{ml})$ & $\mathrm{Sl}^{\mathrm{d}}$ \\
& & $95 \%$ C.l. & & \\
\hline Wa & Salvia cryptantha & $16.3(9.0-29.6)$ & 134.8 & 8.3 \\
& Ballota macrodonta & $8.1(6.9-9.7)$ & 445.5 & 55 \\
& Rindera lanata & $5.8(4.6-7.2)$ & 1179 & 205 \\
\hline
\end{tabular}

${ }^{\mathrm{a}} \mathrm{EC}_{50}$ half maximal effective concentration

${ }^{b} \mathrm{C} . I$. confidence interval

${ }^{\mathrm{c}} \mathrm{CC}_{50}$ half maximal cytotoxic concentration

${ }^{d}$ SI selectivity index

to attach to cells on ice for $1 \mathrm{~h}$ at $4{ }^{\circ} \mathrm{C}$, at a MOI of 0.02. Cells were washed three times, then $R$. lanata methanol extract was added to the cells (at concentrations ranging from $1.2 \mu \mathrm{g} / \mathrm{ml}$ to $300 \mu \mathrm{g} / \mathrm{ml}$ ) and virus particles were allowed to penetrate inside cells for $1 \mathrm{~h}$ at $37{ }^{\circ} \mathrm{C}$. The entry of the viral particles was stopped with two quick washes with $3 \mathrm{mM}$ EGTA in PBS, which releases the outer layer of the virions and causes the particles to detach from the cell surface $[24,25]$; finally, cells were incubated with warm DMEM. After $16 \mathrm{~h}$, cells were fixed and blockade of virus entry were determined by focus reduction assay as described above, and expressed as mean percentages of untreated control \pm SEM. Significant differences were assessed by one way ANOVA, using PRISM 4 (GraphPad Software, San Diego, California, USA).

\section{Rotavirus cell-binding assay}

Confluent MA104 cell monolayers in 24-well trays were washed, incubated with $R$. lanata methanol extract for $2 \mathrm{~h}$ at $37^{\circ} \mathrm{C}$ and cooled on ice for $20 \mathrm{~min}$ in the continuing presence of the extract. Trypsin-activated virus,

Table 2 Quantification of identified phenolic compounds in methanol extract of Rindera lanata by LC ESI MS/MS in negative ionization mode

\begin{tabular}{|c|c|c|c|c|c|}
\hline Analytes & $\mathrm{RT}$ & {$[\mathrm{M}-\mathrm{H}]^{-}(\mathrm{m} / \mathrm{z})$} & $\mathrm{MS}^{2}(\mathrm{~m} / \mathrm{z})$ & Equation & Amount $^{a}$ \\
\hline Quinic acid & 3.36 & 190.95 & 85,93 & $f(x)=33.66 x+25133$ & $2318.60 \pm 111.29$ \\
\hline Malic acid & 3.60 & 133.05 & 115,71 & $f(x)=93.61 x-5673$ & $9381.66 \pm 497.23$ \\
\hline Chlorogenic acid & 5.29 & 353 & 191 & $f(x)=48.98 x+26780$ & $23.63 \pm 1.16$ \\
\hline Protocatechuic acid & 5.51 & 152.95 & 109,108 & $f(x)=36.86 x+6197$ & $32.3 \pm 1.65$ \\
\hline Caffeic acid & 7.11 & 178.95 & $135,134,89$ & $f(x)=1585 x+83958$ & $13.53 \pm 0.70$ \\
\hline p-Coumaric acid & 9.17 & 162.95 & 119,93 & $f(x)=73.53 x+27064$ & $173.59 \pm 8.85$ \\
\hline Rosmarinic acid & 9.19 & 358.9 & 161,133 & $f(x)=18.02 x+1149$ & $706.38 \pm 34.61$ \\
\hline Rutin & 9.67 & 609.1 & $300,271,301$ & $f(x)=51.88+3841$ & $101.89 \pm 5.09$ \\
\hline Hesperidin & 9.69 & 611.1 & 303,465 & $f(x)=1975.77+105641$ & $399.74 \pm 19.59$ \\
\hline Hyperoside & 9.96 & 463.1 & 300,301 & $f(x)=0.98 x+827$ & $118.00 \pm 5.78$ \\
\hline Apigenin & 16.73 & 268.95 & 151,117 & $f(x)=543.79+18525$ & $0.10 \pm 0.005$ \\
\hline Rhamnetin & 18.41 & 314.95 & $165,121,300$ & $f(x)=110.09+632.44$ & $0.23 \pm 0.014$ \\
\hline
\end{tabular}

RT: Retention time

$[\mathrm{M}-\mathrm{H}]^{-}$: Deprotonated ions of the standard compounds

$\mathrm{MS}^{2}$ : MRM fragments for the related molecular ions

a Values in $\mu \mathrm{g} / \mathrm{g}(\mathrm{w} / \mathrm{w})$ of plant methanol extract 
which had been cooled to $4{ }^{\circ} \mathrm{C}$, was allowed to attach to cells on ice for $1 \mathrm{~h}(\mathrm{MOI}=3)$ in presence of $R$. lanata methanol extract. Cells were washed with cold DMEM, followed by addition of cold DMEM. Cells were subjected to two rounds of freeze-thawing, incubated at $37^{\circ} \mathrm{C}$ for $30 \mathrm{~min}$ with $10 \mu \mathrm{g} / \mathrm{ml}$ porcine trypsin to release bound virus, and the lysate clarified by low speed centrifugation for $10 \mathrm{~min}$. Cell-bound virus titers were determined by indirect immunostaining as above. Significant differences were assessed by Student's $t$-test, using PRISM 4 (GraphPad Software, San Diego, California, USA).

\section{Results}

\section{R. lanata methanolic extract is endowed with anti-HRoV activity}

In a first set of experiments, we tested the anti-HRoV activity of $R$. lanata, B. macrodonta and S. cryptantha methanolic extracts against HRoV Wa. Results depicted in Table 1 show that all the methanolic extracts were endowed with anti-HRoV activity, with $\mathrm{EC}_{50} \mathrm{~s}$ ranging from 5.8 to $16.3 \mu \mathrm{g} / \mathrm{ml}$. To exclude the possibility that the antiviral activity might depend on a cytotoxic effect, cell viability assays were performed on uninfected cells, challenged with the extracts under the same conditions as the antiviral assays. Control wells were prepared by treating cells with equal volumes of methanol, corresponding to $6.7 \%(\mathrm{v} / \mathrm{v})$ to $0.0048 \%(\mathrm{v} / \mathrm{v})$ in cell media: these low volumes of methanol were non cytotoxic and did not influence viral replication (data not shown). As shown in Table $1, R$. lanata showed the most favourable selectivity index (SI), i.e. 205. Therefore, we focused our research on $R$. lanata methanolic extract. Firstly, we performed LC-MS/MS analysis to identify and quantify phenolic components that characterize $R$. lanata methanolic extract, in order to make sure of the reproducibility of our study and to ensure that the results of future studies will be comparable to the ones of this research. The LC-MS/MS analysis allowed to identify and quantify twelve phenolic compounds in $R$. lanata methanolic extract and the results are listed in Table 2. Malic acid $(9381.66 \mu \mathrm{g} / \mathrm{g}$ extract) and quinic acid $(2318.60 \mu \mathrm{g} / \mathrm{g})$ were found to be major phenolic component followed by rosmarinic acid $(706.38 \mu \mathrm{g} / \mathrm{g})$ hesperidin $(399.74 \mu \mathrm{g} / \mathrm{g}$

Table 3 Antiviral activity of $R$. lanata methanolic extract against HRoV strains

\begin{tabular}{llll}
\hline HRoV strain & $\mathrm{EC}_{50}^{\mathrm{a}}(\mu \mathrm{g} / \mathrm{ml})-95 \%$ C.I. $^{\mathrm{b}}$ & $\mathrm{CC}_{50}^{\mathrm{c}}(\mu \mathrm{g} / \mathrm{ml})$ & $\mathrm{SI}^{\mathrm{d}}$ \\
\hline HRoV408 & $25.5(15.6-41.6)$ & 1179 & 46 \\
DS-1 & $14.3(6.7-30.2)$ & 1179 & 83
\end{tabular}

${ }^{\mathrm{a}} \mathrm{EC}_{50}$ half maximal effective concentration

${ }^{\mathrm{b} C . I .}$. confidence interval

${ }^{\mathrm{C}} \mathrm{CC}{ }_{50}$ half maximal cytotoxic concentration

${ }^{\mathrm{d}} \mathrm{SI}$ selectivity index
Table 4 Antiviral activity of $R$. lanata methanolic extract against HRhV $1 \mathrm{~A}$ and RSV A2

\begin{tabular}{llcl}
\hline Virus & $\mathrm{EC}_{50}^{\mathrm{a}}(\mu \mathrm{g} / \mathrm{ml})-95 \%$ C.. $^{\text {b }}$ & $\mathrm{CC}_{50}^{\mathrm{c}}(\mu \mathrm{g} / \mathrm{ml})$ & $\mathrm{Sl}^{\mathrm{d}}$ \\
\hline HRhV 1A & n.a. & 804.3 & n.a. \\
RSV A2 & $45.28(30.20-67.88)$ & 183.9 & 4.1 \\
\hline
\end{tabular}

${ }^{\mathrm{a}} \mathrm{EC50}$ half maximal effective concentration

${ }^{\mathrm{b}} \mathrm{C} . \mathrm{I}$. confidence interval

${ }^{\mathrm{C} C}$ 50 half maximal cytotoxic concentration

${ }^{\mathrm{d}} \mathrm{S}$ s selectivity index

n.a. not assessable

extract), $p$-coumaric acid (173.59 $\mu \mathrm{g} / \mathrm{g}$ extract), and hyperoside $(118.00 \mu \mathrm{g} / \mathrm{g}$ extract). In accordance with these results, $R$. lanata belongs to the Boraginaceae family, characterized by the presence of rosmarinic acid and related components [26]

To assess the spectrum of anti-HRoV activity, the extract was tested against two additional HRoV strains, namely HRoV 408 and DS-1. The results reported in Table 3 clearly show that the extract was effective in inhibiting the infectivity of both strains tested, although to a different extent, with $\mathrm{EC}_{50}$ values of $25.5 \mu \mathrm{g} / \mathrm{ml}$ and $14.3 \mu \mathrm{g} / \mathrm{ml}$ respectively. The specificity of the anti-HRoV activity was assessed by performing antiviral assays against two unrelated viruses, namely the rhinovirus (HRhV) and the respiratory syncytial virus (RSV). These were selected for being both RNA viruses as HRoV and representative of naked (HRhV) or enveloped (RSV) viruses. The methanolic extract of $R$. lanata did not show any antiviral activity against HRhV (Table 4) while it was possible to calculate an $\mathrm{EC}_{50}$ against RSV $(45.3 \mu \mathrm{g} / \mathrm{ml})$. However, the selectivity index was very low (4), suggesting that the anti-RSV activity was mainly an expression of a cytotoxic effect (Table 4). Taken together, the results presented so far demonstrate

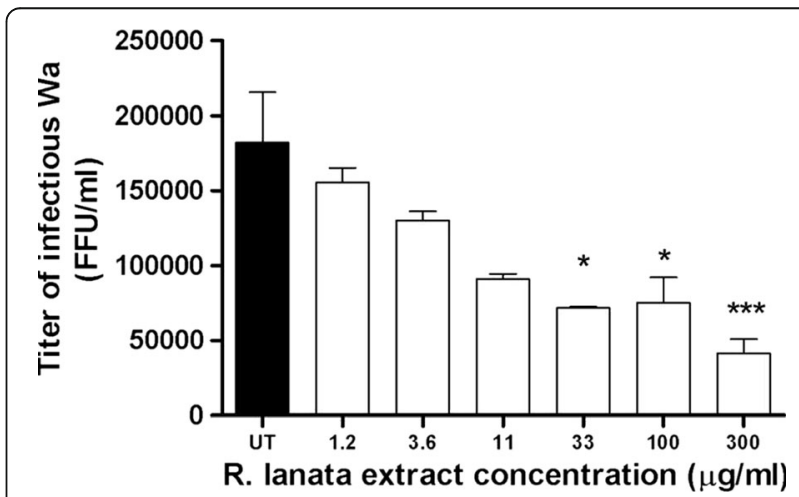

Fig. 1 Effect of methanol extract of $R$. lanata on multiple cycles of HRoV-Wa replication. Cells were treated after virus infection at the given concentrations. The titer of HRoV in the treated samples is expressed as focus-forming units per $\mathrm{ml}(\mathrm{FFU} / \mathrm{ml})$. Error bars represent the SD of the mean of 3 independent experiments. One-way analysis of variance (ANOVA), followed by the Bonferroni test, was used to assess the statistical significance of differences in virus titers. Significance was set at the $95 \%$ level. ${ }^{*} p<0.05 ;{ }^{* * *} p<0.001$ 


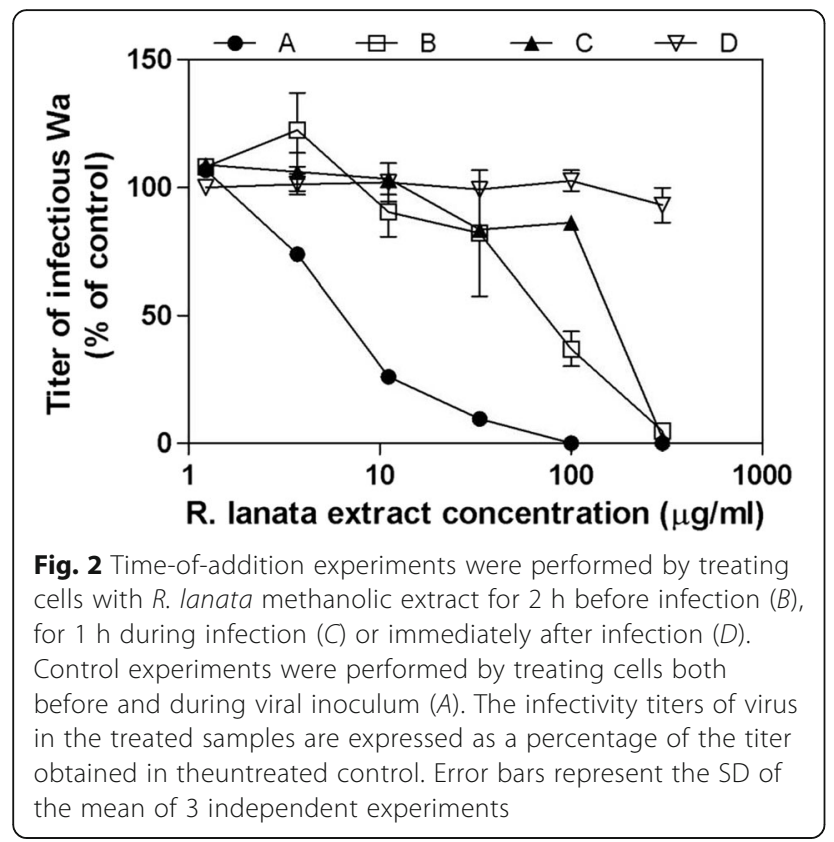

that the $R$. lanata methanolic extract exerts a specific anti-HRoV effect which is not strain restricted.

To investigate further the extract antiviral efficacy, a virus yield reduction assay was performed by treating cells after viral inoculum, and titrating viral progeny. We chose this experimental setting because represents a stringent kind of test, allowing multiple cycles of replication to occur before measuring antiviral activity. Figure 1 shows that the extract significantly $(0.001<$ $\mathrm{p}_{\text {ANOVA }}<0.05$ ) reduced the titer of HRoV progeny in a dose-dependent manner. This result confirms that $R$. lanata methanolic extract affects HRoV replication, likely by targeting a specific step of viral replication.

\section{R. lanata methanolic extract inhibits viral infectivity by targeting the early steps of viral infection}

To investigate the step of viral replication inhibited by the extract, we performed time of addition assays by treating cells with serial dilutions of extract $2 \mathrm{~h}$ before infection or during infection or post-infection. The results, depicted in Fig. 2, show that the first two treatment protocols were active while the latter was not, suggesting a probable activity of the extract on the early steps of HRoV infection. To explore this hypothesis, more stringent tests were performed to assess the putative target of the extract (i.e. the viral particle or the virus-cell interactions). Firstly, we assessed the extract ability to directly inactivate the virus particle by incubating $\mathrm{HRoV}$ with a high concentration $(100 \mu \mathrm{g} /$ $\mathrm{ml}$ ) of methanolic extract and then measuring the viral titer at dilutions corresponding at concentrations that are not antiviral when added on cells. Results depicted in Fig. 3a demonstrate that the methanolic extract did not inactivate the virus particles. Having excluded the virus particle as a target of the antiviral activity of the extract, we explored the possibility that the interaction between
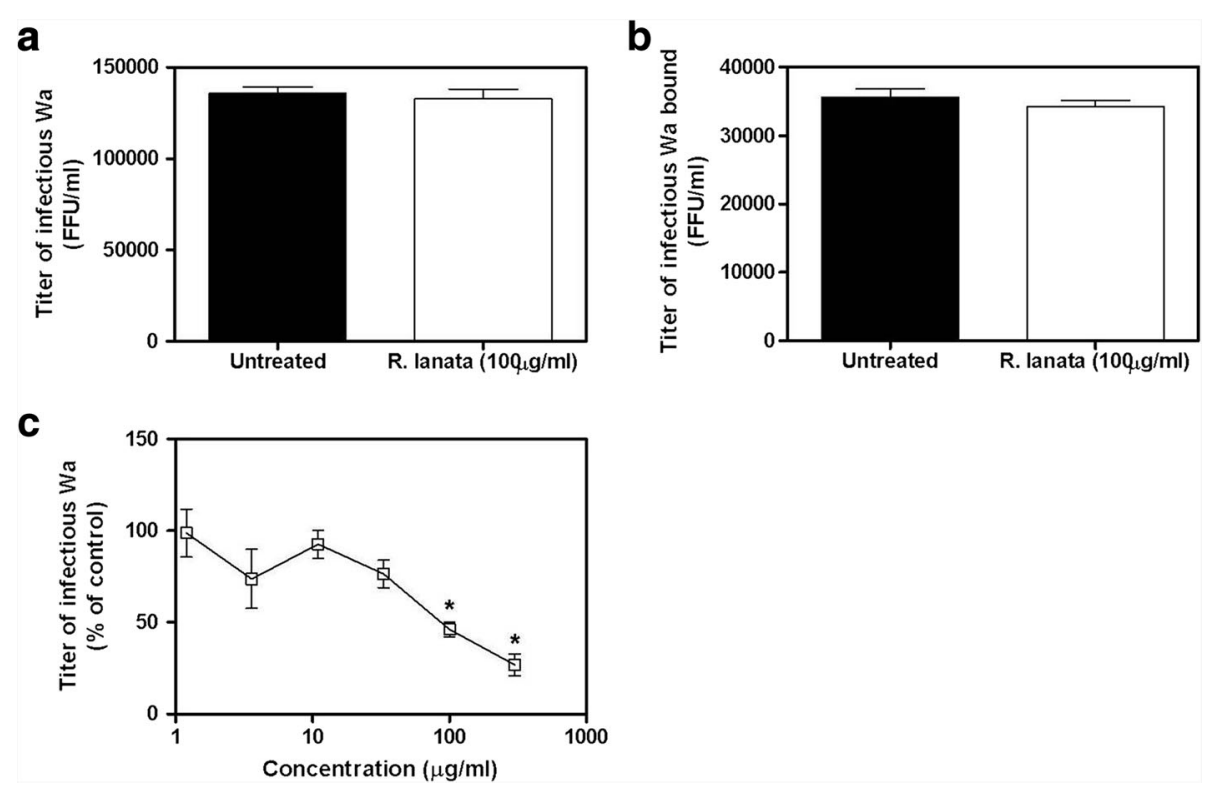

Fig. 3 Investigation of the mechanism of anti-HRoV action of $R$. lanata methanol extract. Panel a shows the evaluation of the virucidal effect of $R$. lanata methanol extract on infectious HRoV particles. On the $y$ axis, the HRoV Wa infectious titers are expressed as focus-forming units per ml (FFU/ml). Panel $\mathbf{b}$ displays the effect of $R$. lanata methanol extract on Wa binding to the MA104 cell surface; on the $y$ axis, the infectious titer of Wa bound to cells is expressed as a \% of the titer bound to control MA104 cells in the absence of treatment. Panel c shows the effect of R. lanata methanol extract on HRoV-Wa entry into MA104 cells; the viral titer measured in the treated samples is expressed as a \% of the titer obtained in the untreated control. On the three graphs, error bars represent the SD of the mean of 3 independent experiments.* $p<0.05$ 
the viral particles and the cell surface could be affected by the extract. To this aim HRoV-cell binding assays were performed. The results (Fig. 3b) demonstrate that the treatment did not reduce significantly $(p>0.05)$ the titer of virus particles bound to the surface of treated cells, thus suggesting that inhibition occurs at a post-binding stage. To verify this hypothesis, entry assays were performed by treating cells during virus penetration. Figure $3 \mathrm{c}$ shows that the $R$. lanata methanolic extract significantly reduced HRoV infectivity in a dose-dependent manner when added immediately after the virus-cell attachment step (i.e. during cell penetration).

\section{Discussion}

Several recent studies demonstrate that plant extracts are deeply explored for their antiviral potential against HRoV [9-14, 27-29].

In this study we show that the methanolic extract of $R$. lanata is endowed with anti-HRoV activity. Although several molecules inside this crude extract can contribute to its effect, each one acting through a specific mechanism, some preliminary conclusions can be drawn on the main mechanism of antiviral action. The treatment with the methanolic extract of $R$. lanata does not alter the ability of HRoV to attach on the host cell surface, as shown by the results of the binding experiments; moreover, the results of the virus inactivation assays rule out a direct antiviral effect of any component of $R$. lanata methanolic extract. By contrast, the results suggest that inhibition takes place at a post-attachment stage, since no antiviral effect is shown when the methanolic extract is added on cells $1 \mathrm{~h}$ after the viral inoculum (Fig. 2) - i.e. when the entry process already started and the $30 \%$ of the inoculated $\mathrm{HRoV}$ particles already entered inside cells [30]. Nevertheless, since the inhibition of entry is not complete it is likely that other, yet unidentified mechanisms, contribute to the overall antiviral activity of the extract. Of note, cells pre-treatment with the extract affects their susceptibility to the HRoV infection (Fig. 2) suggesting that the extract may target cellular functions required for virus replication. Among the major phenolic compounds present in the methanol extract of $R$. lanata hesperidin is known to a have antiHRoV activity [31] and might be responsible, at least in part, to the anti-HRoV effect of the extract.

\section{Conclusion}

In conclusion, the favorable selectivity index and the anti-HRoV activity against multiple viral strains make the R.lanata extract a promising starting material for a bioguided-fractionation aimed at identifying anti-HRoV compounds. Further work remains to be done in order to isolate the active principle, elucidate its mechanism of action and assess its clinical potential.

\section{Abbreviations}

[M-H]: Deprotonated ions of the standard compounds; C.I.: Confidence interval; $C_{50}$ : Half maximal cytotoxic concentration; CPE: Cytopathic effect; DMEM: Dulbecco's Modified Eagle Medium; $\mathrm{EC}_{50}$ : Half maximal effective concentration; FBS: Fetal bovine serum; FFU/ml: Focus-forming units per ml; HRhV: Human rhinovirus; HRoV: Human rotavirus; MEM: Eagle's minimal essential medium; MOI: Multiplicity of infection; MS 2: MRM fragments for the related molecular ions; RSV: Respiratory syncytial virus; RT: Retention time; Sl: Selectivity index

\section{Acknowledgements}

We are grateful to Violetta Legnani for her donation.

\section{Funding}

This work was supported by a donation from Violetta Legnani.

\section{Availability of data and materials}

The datasets used and/or analysed during the current study available from the corresponding author on reasonable request.

\section{Authors' contributions}

AC was involved in conception, data interpretation and supervision of this work. AC, RF and DS performed the antiviral assays with HRoV and HRhV. MD was involved in data interpretation and manuscript revision (antiviral assays data). VC performed the antiviral assays with RSV. PR was involved in supervision, data interpretation and deep manuscript revision (phytochemical data). GZ, AU and RC collected the plant material and performed the extraction and the LC-MS/MS analysis of the Rindera lanata methanolic extract. DL supervised the work on the whole and provided laboratory means for the antiviral assays. All authors read and approved the final manuscript.

\section{Authors' information}

AC is post doctoral fellow researcher working in the Laboratory of Molecular Virology, University of Turin, Italy.

RF and DS are post graduate researchers working in the Laboratory of Molecular Virology, University of Turin, Italy.

$\mathrm{GZ}$ is a research assistant working at the University of Selcuk.

$\mathrm{AU}$ is an assistant Professor working at the University of Selcuk.

$\mathrm{RC}$ is a phD student working at the University of Selcuk.

$\mathrm{MD}$ is an assistant Professor working in the Laboratory of Molecular Virology, University of Turin, Italy.

VC is post doctoral fellow researcher working in the Laboratory of Molecular Virology, University of Turin, Italy.

PR is Professor, Senior lecturer working in the Laboratory of Phytoanalysis at the Department of Drug Science and Technology, University of Turin, Italy. DL is Professor, Head of the Laboratory of Molecular Virology, University of Turin, Italy. He is also Donalisio's, Civra's, Cagno's, Francese's and Sinato's research supervisor.

\section{Competing interests}

The authors declare that they have no competing interests.

\section{Consent for publication \\ Not applicable.}

\section{Ethics approval and consent to participate}

This information is not relevant for the study.

\section{Author details}

'Department of Clinical and Biological Sciences, University of Torino, S. Luigi Gonzaga Hospital, Regione Gonzole, 10, 10043 Orbassano, Torino, Italy. ${ }^{2}$ Dipartimento di Scienza e Tecnologia del Farmaco, Università degli Studi di Torino, 10125 Torino, Italy. ${ }^{3}$ Department of Biology, Science Faculty, Selcuk University, Konya, Turkey. ${ }^{4}$ Deparment of Medicinal Laboratory, Vocational School of Health Services, Selcuk University, Konya, Turkey.

Received: 17 June 2016 Accepted: 4 January 2017 Published online: 24 January 2017 


\section{References}

1. Guarino A, Dupont C, Gorelov AV, Gottrand F, Lee JK, Lin Z, Lo Vecchio A, Nguyen TD, Salazar-Lindo E. The management of acute diarrhea in children in developed and developing areas: from evidence base to clinical practice. Expert Opin Pharmacother. 2012;13:17-26.

2. Albano F, Bruzzese E, Bella A, Cascio A, Titone L, Arista S, Izzi G, Virdis R, Pecco P, Principi N, Fontana M, Guarino A. Rotavirus and not age determines gastroenteritis severity in children: a hospital-based study. Eur J Pediatr. 2007;166:241-7.

3. Kotloff KL, Nataro JP, Blackwelder WC, Nasrin D, Farag TH, Panchalingam S, Wu Y, Sow SO, Sur D, Breiman RF, Faruque AS, Zaidi AK, Saha D, Alonso PL, Tamboura B, Sanogo D, Onwuchekwa U, Manna B, Ramamurthy T, Kanungo S, Ochieng JB, Omore R, Oundo JO, Hossain A, Das SK, Ahmed S, Qureshi S, Quadri F, Adegbola RA, Antonio M, Hossain MJ, Akinsola A, Mandomando I, Nhampossa T, Acácio S, Biswas K, O'Reilly CE, Mintz ED, Berkeley LY, Muhsen K, Sommerfelt H, Robins-Browne RM, Levine MM. Burden and aetiology of diarrhoeal disease in infants and young children in developing countries (the Global Enteric Multicenter Study, GEMS): a prospective, case-control study. Lancet. 2013;382:209-22.

4. Forster J, Guarino A, Parez N, Moraga F, Román E, Mory O, Tozzi AE, de Aguileta A, Wahn U, Graham C, Berner R, Ninan T, Barberousse C, Meyer N, Soriano-Gabarró M, Rotavirus Study Group. Hospital-based surveillance to estimate the burden of rotavirus gastroenteritis among European children younger than 5 years of age. Pediatrics. 2009;123:393-400.

5. Parashar UD, Gibson CJ, Bresee JS, Glass RI. Rotavirus and severe childhood diarrhea. Emerg Infect Dis. 2006;2:304-6.

6. de Rougemont A, Kaplon J, Pillet S, Mory O, Gagneur A, Minoui-Tran A, Meritet JF, Mollat C, Lorrot M, Foulongne V, Gillet Y, Nguyen-Bourgain C, Alain S, Agius G, Lazrek M, Colimon R, Fontana C, Gendrel D, Pothier P, French Rotavirus Network. Molecular and clinical characterization of rotavirus from diarrheal infants admitted to pediatric emergency units in France. Pediatr Infect Dis J. 2011;30:118-24.

7. Palumbo E, Branchi M, Malorgio C, Siani A, Bonora G. Diarrhea in children: etiology and clinical aspects. Minerva Pediatr. 2010;62:347-51.

8. Guarino A, Ansaldi F, Ugazio A, Chiamenti G, Bona G, Correra A, Di Pietro P, Mele G, Sapia MG, Società Italiana di Pediatria. [Italian Pediatrician's consensus statement on anti-Rotavirus vaccines]. Minerva Pediatr. 2008;60:3-16.

9. Alfajaro MM, Kim HJ, Park JG, Ryu EH, Kim JY, Jeong YJ, Kim DS, Hosmillo M, Son KY, Lee JH, Kwon HJ, Ryu YB, Park SJ, Park SI, Lee WS, Cho KO. Antirotaviral effects of Glycyrrhiza uralensis extract in piglets with rotavirus diarrhea. Virol J. 2012;9:310.

10. Cecílio AB, de Faria DB, Oliveira Pde C, Caldas S, de Oliveira DA, Sobral ME, Duarte MG, Moreira CP, Silva CG, de Almeida VL. Screening of Brazilian medicinal plants for antiviral activity against rotavirus. J Ethnopharmacol. 2012;14:975-81.

11. Gonçalves JL, Lopes RC, Oliveira DB, Costa SS, Miranda MM, Romanos MT, Santos NS, Wigg MD. In vitro anti-rotavirus activity of some medicinal plants used in Brazil against diarrhea. J Ethnopharmacol. 2005;99:403-7.

12. Knipping K, Garssen J, Van't Land B. An evaluation of the inhibitory effects against rotavirus infection of edible plant extracts. Virol J. 2012;9:137.

13. Roner MR, Tam Kl, Kiesling-Barrager M. Prevention of rotavirus infections in vitro with aqueous extracts of Quillaja Saponaria Molina. Future Med Chem. 2013;2:1083-97.

14. Téllez MA, Téllez AN, Vélez F, Ulloa JC. In vitro antiviral activity against rotavirus and astrovirus infection exerted by substances obtained from Achyrocline bogotensis (Kunth) DC. (Compositae). BMC Complement Altern Med. 2005;15:428.

15. Ozcan T. Analysis of the total oil and fatty acid composition of seeds of some Boraginaceae taxa from Turkey. Plant Syst Evol. 2008;274:143-53.

16. Bigazzi M, Nardi E, Selvi F. Palynological Contribution to the Systematics of Rindera and the Allied Genera Paracaryum and Solenanthus (BoraginaceaeCynoglosseae). Willdenowia 2006;36:37-46.

17. Altundag E, Ozturk M. Ethnomedicinal studies on the plant resources of east Anatolia, Turkey. Procedia Soc Behav Sci. 2001;19:756-77.

18. Mosaddegh M, Naghibi F, Moazzeni H, Pirani A, Esmaeili S. Ethnobotanical survey of herbal remedies traditionally used in Kohghiluyeh va Boyer Ahmad province of Iran. J Ethnopharmacol. 2012;141:80-95.

19. Ertaş A, Bog AM, Yılmaz MA, Yeșil Y, Așimi N, Kaya MS, Temel H, Kolak U. Chemical compositions by using LC-MS/MS and GC-MS and biological activities of Sedum sediforme (Jacq.) Pau. J Agric Food Chem. 2014;62:4601-9.
20. Ertas A, Bog AM, Yilmaz MA, Yesil Y, Tel G, Temel H, Hasimi N, Gazioglu I, Ozturk M, Ugurlu P. A detailed study on the chemical and biological profiles of essential oil and methanol extract of Thymus nummularius (Anzer tea): Rosmarinic acid. Ind Crops Prod. 2005;67:336-45.

21. Ceylan R, Kathanic J, Zengin G, Matic S, Aktumsek A, Borojab T, Stanic S, Mihailovic V, Gulerd OG, Boga M, Yılmazf MA. Chemical and biological fingerprints of two Fabaceae species (Cytisopsis dorycniifolia and Ebenus hirsuta): Are they novel sources ofnatural agents for pharmaceutical and food formulations? Ind Crops Prod. 2016;84:254-62.

22. Civra A, Cagno V, Donalisio M, Biasi F, Leonarduzzi G, Poli G, Lembo D. Inhibition of pathogenic non-enveloped viruses by 25 -hydroxycholesterol and 27-hydroxycholesterol. Sci Rep. 2014;4:7487.

23. Cagno V, Donalisio M, Civra A, Volante M, Veccelli E, Oreste P, Rusnati M, Lembo D. Highly sulfated K5 Escherichia coli polysaccharide derivatives inhibit respiratory syncytial virus infectivity in cell lines and human trachealbronchial histocultures. Antimicrob Agents Chemother. 2014;58:4782-94.

24. Cohen J, Laporte J, Charpilienne A, Scherrer R. Activation of rotavirus RNA polymerase by calcium chelation. Arch Virol. 1979;60:177-86.

25. Estes MK, Graham DY, Smith EM, Gerba CP. Rotavirus stability and inactivation. J Gen Virol. 1979;43:403-9.

26. Petersen M. Rosmarinic acid: new aspects. Phytochem Rev. 2013;12:207-27.

27. Sun Y, Gong X, Tan JY, Kang L, Li D, Vikash, Yang J, Du G. In vitro Antiviral Activity of Rubia cordifolia Aerial Part Extract a Rotavirus. Front Pharmacol. 2016 Sep 13;7:308

28. Alfajaro MM, Rho MC, Kim HJ, Park JG, Kim DS, Hosmillo M, Son KY, Lee JH, Park SI, Kang MI, Ryu YB, Park KH, Oh HM, Lee SW, Park SJ, Lee WS, Cho KO. Anti-rotavirus effects by combination therapy of stevioside and Sophora flavescens extract. Res Vet Sci. 2014;96(3):567-75.

29. Chingwaru W, Majinda RT, Yeboah SO, Jackson JC, Kapewangolo PT, Kandawa-Schulz M, Cencic A. Tylosema esculentum (marama) tuber and bean extracts Are strong antiviral agents against rotavirus infection. Evid Based Complement Alternat Med. 2011;2011:284795.

30. Gutiérrez M, Isa P, Sánchez-San Martin C, Pérez-Vargas J, Espinosa R, Arias CF, López S. Different rotavirus strains enter MA104 cells through different endocytic pathways: the role of clathrin-mediated endocytosis. J Virol. 2010;84:9161-9.

31. Bae EA, Han MJ, Lee M, Kim DH. In vitro inhibitory effect of some flavonoids on rotavirus infectivity. Biol Pharm Bull. 2000;23:1122-4.

\section{Submit your next manuscript to BioMed Central and we will help you at every step:}

- We accept pre-submission inquiries

- Our selector tool helps you to find the most relevant journal

- We provide round the clock customer support

- Convenient online submission

- Thorough peer review

- Inclusion in PubMed and all major indexing services

- Maximum visibility for your research

Submit your manuscript at www.biomedcentral.com/submit 